\title{
SELECTING THE PLACE FOR INSTALLATION OF PRESSURE SENSORES FOR REGISTRATION OF OSCILLATORY PROCESSES OF FUEL
}

\author{
M. Bulgakov, Assoc. Prof., Ph. D. (Eng.), E. Zenkin, Assoc. Prof., Ph. D. (Eng.), \\ Kharkov National Automobile and Highway University
}

\begin{abstract}
The article deals with the possibility of using various pressure control devices for diagnosing the units of gasoline engine. Diagnosing is offered to be carried out using the fluctuations of fuel pressure oscillation in a fuel rail. Research on various fuel systems is conducted and is used in various modes of sensors connection..
\end{abstract}

Key words: fuel, gasoline, oscillation process, rail, technique, sensor, injector, pressure dropping, diagnosis, oscillogram.

\section{ВИБІР МІСЦЯ РОЗТАШУВАННЯ ДАТЧИКІВ ДЛЯ РЕССТРАЦЇ̈ ПРОЦЕСІВ КОЛИВАННЯ ПАЛИВА}

М.П. Булгаков, доц., к.т.н., Є.Ю. Зенкін, доц., к.т.н., Харківський національний автомобільно-дорожній університет

\begin{abstract}
Анотація. Визначено місие для розташування різних типів датчиків тиску для реєстрації проиесів коливання палива в паливній рампі. Визначено вимоги до датчиків. Отримані результати можуть бути використані для діагностування будь-яких систем із впорскуванням палива у впускний колектор.
\end{abstract}

Ключові слова: датчик, форсунка, тиск, діагностування, осцилограма.

\section{ВЫБОР МЕСТА РАСПОЛОЖЕНИЯ ДАТЧИКОВ ДЛЯ РЕГИСТРАЦИИ ПРОЦЕССОВ КОЛЕБАНИЯ ТОПЛИВА}

\author{
Н.П. Булгаков, доц., к.Т.н., Е.Ю. Зенкин, доц., к.т.н., \\ Харьковский национальный автомобильно-дорожный университет
}

\begin{abstract}
Аннотация. Определено место для установки различных типов датчиков давления для регистрачии процессов колебания топлива в топливной ралпе. Определены требования к датчикам. Полученные результаты могут быть использованы для диагностирования любых систем со впрыском топлива во впускной коллектор.
\end{abstract}

Ключевые слова: датчик, форсунка, давление, диагностирование, осциллограмма.

\section{Introduction}

With the advent of electronic engine management systems there automatically appeared the need to change the approaches to diagnosis, the parameters of diagnosis increased and dramatically enhanced the role of computer technology in the process of maintenance and diagnosis of modern vehicles. With the advent of electronic engine management systems there automatically appeared the need to change the approaches to diagnostics, the parameters of diagnostics have increased and dramatically enhanced the role of computer technology in the processes of maintenance and enlarged the role in diagnosis of modern vehicles. In this work they considered the development of measuring stand. The use of this stand allows to registrate the fuel pressure oscillation in the fuel system of vehicles. It is supposed to make it possible to install two dif- 
ferent type of sensors into the fuel system (it is depends on design of system) to define its signal and based on this data to research the influence sensors' location on the correctness of showing the fluctuation processes. Thus, a reliable and informative source will be given. In the future, these parameters will allow to estimate the technical condition of injectors, electrical fuel pump and fuel pressure regulator.

\section{Analysis of publications}

During vehicles operation, approximately $31 \%$ of malfunctions depend on the injectors [1]. Wherein, the checking of it needs a lot of time [2], so, this way, the time of vehicle service at the service station increases. Estimation of the amplitude, frequency, pressure oscillation waveforms will speed up the process of diagnosis and repair of fuel equipment [1]. The efficiency of this method is confirmed [1], [3], [5], but a reliable method of diagnosing of fuel equipment is not currently developed [4].

\section{The purpose and problem statement}

During the fuel system operation, such units as fuel pump, injectors and fuel regulator pressure (FRP) oscillation are arising in a hydraulic part of system [3]. Analysis of frequency and amplitude of these changes allow to define the technical condition of fuel system units and the character of the aforementioned elements operation [1].

The aim of the research is to determine the influence of the installation site and the type of pressure sensor on the accuracy of recording the oscillating processes in the fuel injection system of petrol engine.

To achieve the goal, it is necessary to solve the following tasks:

- to define sensitivity of each sensors to fluctuations of pressure in a fuel rail;

- to define the place for installation of pressure control devices for registration of oscillatory processes.

\section{Results of the research}

Depending on the condition of a gasoline pump fluctuations of the frequency and amplitude will change, and will also change the average level of pressure. Depending on the duration of injection and from the extent of its blockage, the fuel pressure amplitude at injection will be changed. Depending on the condition of pressure regulator, the average level of fuel pressure in a fuel rail will change as well, but the serviceable fuel pressure regulator doesn't cause oscillation of fuel pressure [1].

PST-F and PSS-260 pressure control sensores were used in researching.

The PST-F pressure control sensor is intended for measurement of absolute pressure and temperature of different types of liquids, for example diesel fuel, gasoline, and oil. This sensor has an opportunity to trace the fuel temperature besides registrate the parameters of pressure at the same time. The limits of measurement of pressure is $0,5-6$ bars $(0,005-0,06 \mathrm{MPa})$. PST-F is equipped with the piezoresistive element of pressure which is integrated into the silicon chip with elements of increasing of a signal (amplifier). Thermo-sensitive element is the NTC resistor. The range of measurement of temperature is from 40 to $125^{\circ} \mathrm{C}$. It has a straight-line characteristic.

The PSS-260 pressure control device is developed for measurement of absolute pressure in the fuel system of direct injection. The range of measurement of pressure is from 0 to 140 bars (0-14 MPa). This sensor is also compatible to other types of liquids, for example diesel fuel, engine oil, transmission oil or braking fluids. The piezoresistive sensitive element is the resistive bridge of Winston. The sensor provides measurement of pressure irrespective of atmospheric pressure. Both have the linear characteristic thanks to the amplifier of the sensors. Parameters of power supply of sensors and their output signals are standardized, both sensors have three-contact connection in which there are «negative ground», power supply of 5 volts and information channel in the range from 0,5 to 5 volts.

For carrying out measurements by means of sensors the eight-channel digital USB-type oscillograph was involved. It allowed to record several signals at the same time: voltage on the information channel of the sensor, current in the coil of injectors, duration signal's managing in the coil of injectors. Also, in addition airflow was recorded using the mass air flow sensor as an auxiliary value. As we know from the analysis of waveforms of the control pulse of the injector - using an injector's signal of power supply voltage can be traced to the time when a needle 
be settled down, that means until the fuel will be overlapped. Using a voltage signal that is measured with current clamp - can determine when is the moment of full opening of the injector flow section and when the needle went up to the maximum position [6]. In this work is also attempted to compare these moments with the change of the fuel pressures, when it is injected.

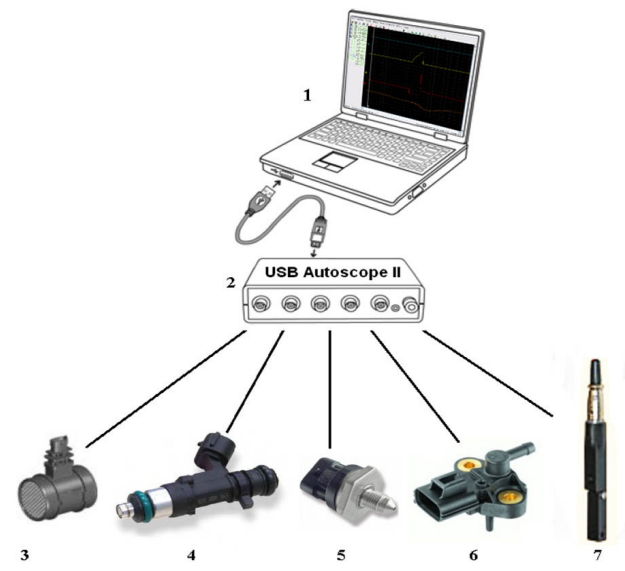

Fig. 1. Elements of measuring system: $1-$ the laptop with specialized software; 2 - digital oscillograph USB-type; 3 - mass air flow sensor; 4 - injector; 5 - pressure sensor PSS-260; 6 - pressure sensor PST; 7 - current clamp

The tests were conducted on the following vehicles Skoda Octavia 1.8 Turbo and VW Golf GTI. Depending on the design of a fuel rail, various modes of connection of fuel pressure sensors to hydraulic system of the fuel equipment were tested.

On Skoda car the pressure sensor was connected by means of a $\mathrm{T}$-connector to a supply line at an angle of $90^{\circ}$ on the entrance to the fuel rail (fig. 2, pos. 10).

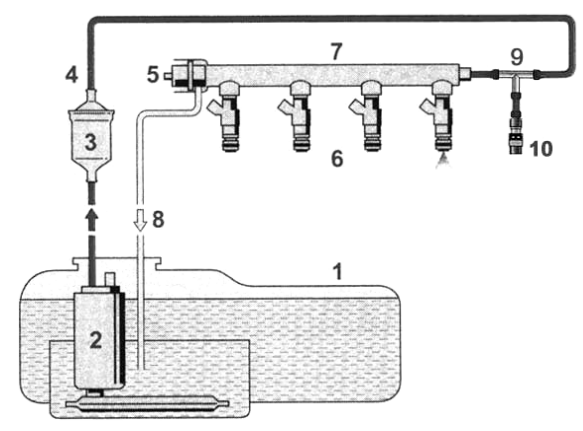

Fig. 2. The scheme of connection of the pressure sensor on Skoda Octavia car 1.8T: 1 - fuel tank; 2 - fuel pump; 3 - fuel filter; 4 pressure line; 5 - FPR; 6 - injectors; 7 fuel rail; 8 - line of the fuel returning ; 9 $\mathrm{T}$-connector; 10 - pressure sensor
Thanks to the design of fuel rail on the VW Golf GTI, it is possible to connect the pressure sensor directly to a fuel rail (fig. 3, pos. 9).

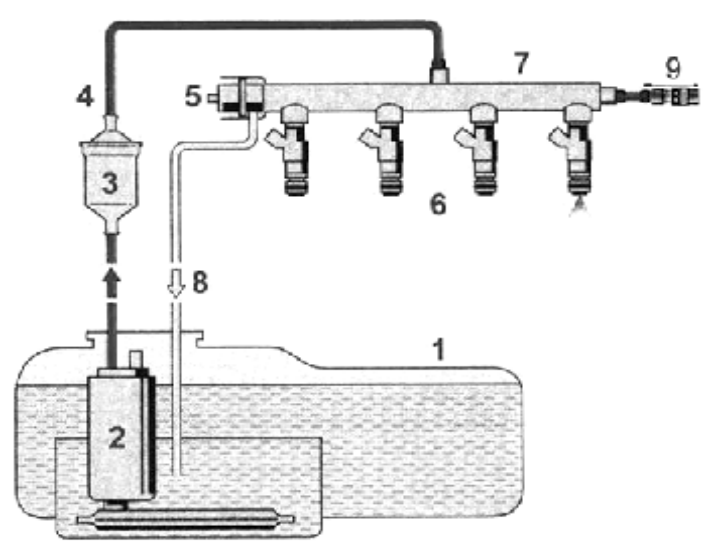

Fig. 3. The scheme of connection of the pressure sensor on the VW Golf GTI: 1 - fuel tank; 2 - fuel pump; 3 - fuel filter; 4 - pressure line; 5 - FPR; 6 - injectors; 7 - fuel rail; 8 - line of the fuel returning; 9 - pressure sensor

In the analysis of the oscillograms which were received in the such way of connection of the pressure sensor, the next conclusion was made: this technique is unsuitable for receiving reliable information about the hydraulic processes of oscillation in a fuel rail. Using the PST-F sensor, the fluctuations of pressure were visible, but they had the smoothed characteristic unsuitable for getting from it any useful information (fig. 4).

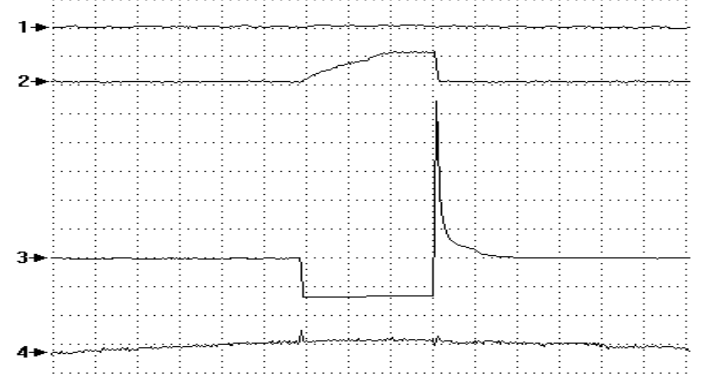

Fig. 4. Oscillograms with PST-F pressure sensor on the stabilized mode of engine of the Skoda Octavia 1,8 T: 1 - air consumption; 2 - current on the steering signal of injectors , 3 - steering signal of a fuel injection; 4 - fuel pressure

The PSS-260 sensor, under this made of connection, fixed the general change of pressure in a fuel system, but for the misfit of working range and sensitivity of the sensor to amplitude processes of fluctuation weren't noticed (fig. 5). 


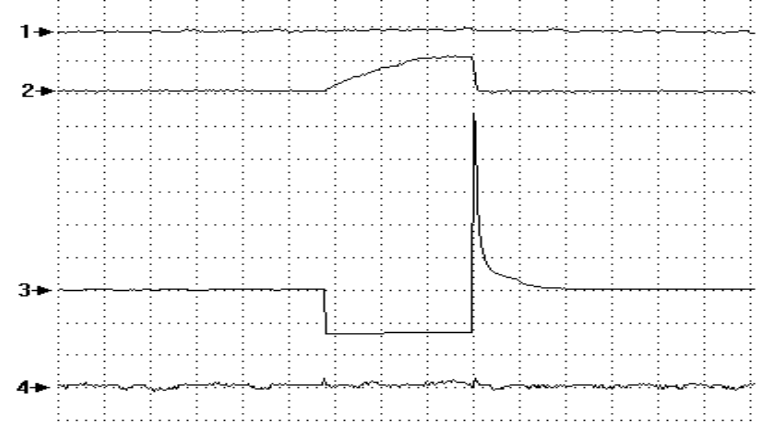

Fig. 5. Oscillograms with PSS-260 pressure sensor on the stabilized mode of engine of the Skoda Octavia 1,8 T: 1 - air consumption; 2 - current on the steering signal of injectors, 3 - steering signal of a fuel injection; 4 - fuel pressure

Connected via the union for pressure testing, the PST-F sensor registered falling of pressure at fuel injection. The dropping of pressure is well seen in the fig. 6 .

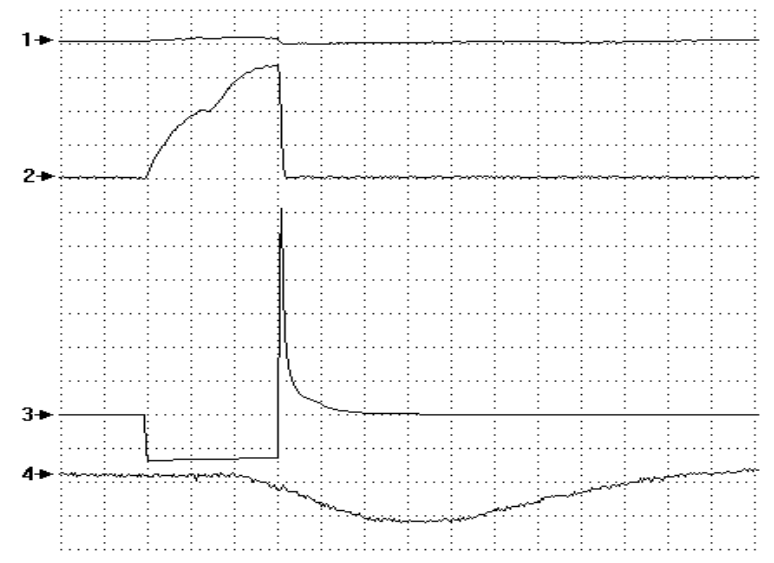

Fig. 6. Oscillograms with PST-F pressure sensor on the stabilized mode of engine of the VW Golf GTI: 1 - air consumption; 2 - current on the steering signal of injectors, 3 steering signal of a fuel injection; 4 - fuel pressure

Using the PSS-260 pressure sensor only the rising of the general pressure (fig. 7) was observed.

As it was shown analysis of the received oscillograms, the directly connection to the rail was the most informative. Using the signal which is recorded by means of the PST-F sensor, observation of the deep dropping of pressure at the moment of injection (fig. 6) became possible.

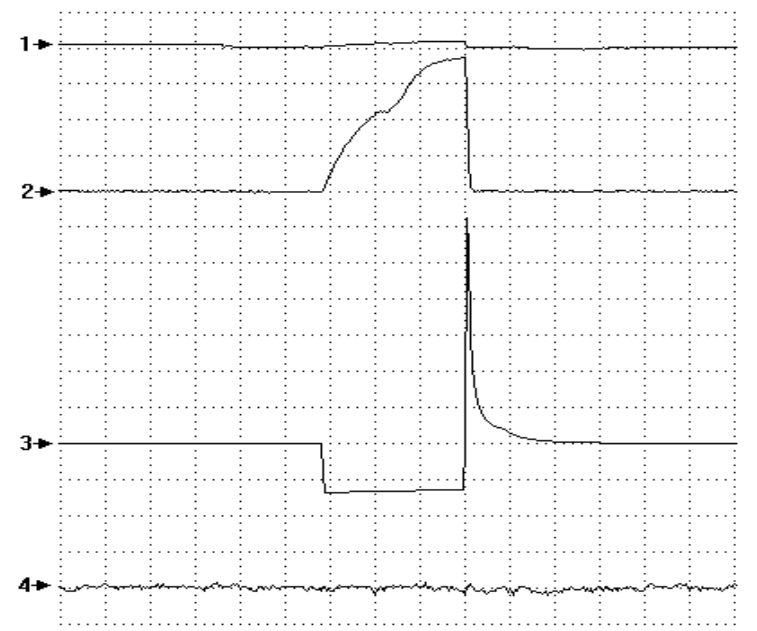

Рис. 7. Oscillograms with PSS-260 pressure sensor on the stabilized mode of engine of the VW Golf GTI: 1 - air consumption; 2 current on the steering signal of injectors, 3 - steering signal of a fuel injection; 4 - fuel pressure

The PSS-260 sensor didn't fixe the fluctuations because of the working range and sensitivity of the sensor to the amplitude were not enough for the registration of oscillations in the fuel system (fig. 5).

\section{Conclusions}

Receiving reliable information about processes in the fuel system is possible only with the connection of the pressure sensor directly to a fuel rail.

Connecting the pressure sensor to a supply line of the fuel system, it was possible to observe pressure changes, but for diagnosing this technique of connection isn't enough informative and reliable.

The PSS-260 pressure control sensor is unsuitable for obtaining full information about the oscillatory processes in the fuel system of the gasoline engine with injection in an intake manifold, because of the big range (0-14 MPa) of the measured pressure and according to small sensitivity in the range of pressure of this fuel equipment $(0,025-0,035 \mathrm{MPa})$.

On the other hand, the PST-F pressure control sensor is suitable for receiving reliable information about the oscillatory processes in the fuel system of the gasoline engine with injection in an intake manifold. 


\section{References}

1. Stiesch G. Modeling Engine Spray and Combustion Processes / G. Steisch. - Berlin: Springer, 2003. $-282 \mathrm{p}$.

2. Автомобильный справочник / Пер. с англ. - 2-е изд., перераб. и доп. - М.: ЗАО «КЖИ «За рулем», 2004. - 992 с.

3. Кучер В.П. Диагностика японских автомобилей / В.П. Кучер. - М.: Легион - Автодата, 2004. - $176 \mathrm{c}$.

4. Булгаков М.П. Діагностування паливних систем 3 безпосереднім упорскуванням за коливаннями тиску палива у рампі / М.П. Булгаков // Вісник НТУ «ХПІ»: зб. наук. пр. - 2014. - № 9 (1052). C. $140-145$.

5. Пойда А.Н. Анализ технического состояния топливной аппаратуры на основе колебаний давления топлива в гидроаккумуляторе / А.Н. Пойда, Е.Ю. Зенкин // Вестник НТУ «ХПИ»: сб. науч. тр. 2009. - №1. - C. 114-118.

6. Зенкин Е.Ю. Диагностика в эксплуатации автомобильных дизелей с помощью ЭВМ / Е.Ю. Зенкин // Автомобильный транспорт: сб. науч. тр. - 2005 . Вып. 16. - С. 73-75.

\section{References}

1. Stiesch G. Modeling Engine Spray and Combustion Processes, Berlin, Springer Publ., 2003, $282 \mathrm{p}$.
2. Avtomobil'nyj spravochnik [Automobile reference book], Moscow, Za rulem Publ., 2004, 992 p.

3. Kucher V.P. Diagnostika yaponskikh avtomobiley [Diagnosis of the Japanese cars], Moscow, Legion-Avtodata Publ., 2004, $176 \mathrm{p}$.

4. Bulgakov M.P. Diagnostuvannya palivnikh sistem $z$ bezposerednim uporskuvannyam za kolivannyami tisku paliva u rampi [Diagnosis of fuel systems with direct injection using pressure oscillation]. Visnyk NTU «KhPI», 2014, no. 9 (1052), pp. 140-145.

5. Poyda A.N., Zenkin E.Yu., Analiz tekhnicheskogo sostoyaniya toplivnoy apparatury na osnove kolebaniy davleniya topliva $v$ gidroakkumulyatore [The analysis of technical condition of the fuel equipments biasing of fluctuations of fuel pressure in the hydroaccumulator], Visnyk NTU «KhPI», 2009, no. 1, pp. 114-118.

6. Zenkin E.Yu. Diagnostika $v$ ekspluatatsii avtomobil'nykh dizeley $s$ pomoshch'yu EVM [Diagnosis of automobile diesels by means of the computer in operation]. Avtomobil'nyy transport, 2005, no. 16. pp. 73-75.

Рецензент: В.П. Волков, профессор, д.т.н., ХНАДУ. 